\title{
2,5-Dihydroxy-3-heptadecyl-1,4-benzoquinone and Stigmasterol from Heliotropium indicum $L$.
}

\author{
Md. Nazmul Hasan, Monira Ahsan, Choudhury Mahmood Hasan \\ and A.T.M. Zafrul Azam
}

\begin{abstract}
Phytochemical Research Laboratory, Department of Pharmaceutical Chemistry, Faculty of Pharmacy, University of Dhaka, Dhaka-1000, Bangladesh
\end{abstract}

Received: March 30, 2016; Accepted: June 02, 2016; Published (web): June 20, 2016

From the crude methanol extract of whole plant of Heliotropium indicum L., two compounds 2,5dihydroxy-3-heptadecyl-1,4-benzoquinone (1) and stigmasterol (2) were isolated by a combination of column chromatography and preparative thin layer chromatography over silica gel. The structure of these compounds were determined by ${ }^{1} \mathrm{H}$ NMR spectroscopic method and by comparing with published data.

H. indicum (Bengali name Hatisur; FamBoraginaceae) is a small to medium-sized, muchbranched, evergreen plant of the family native to Asia. It is also widely available throughout Bangladesh in fallow lands. ${ }^{1}$ Different parts of the plant are used as astringent, emollient, diuretic, ulcers, sores and wounds, stings of insects, eye disease, fever and rheumatism. Leaves are used for ringworm; juice is used in fever. Roots are used aphrodisiac, for the cure of night blindness. The flowers are considered emmenagogue in small doses and abortifacient in large doses. ${ }^{2}$ Aqueous and alcoholic extract of roots are oxytocic. ${ }^{3}$ Previous studies also led to the isolation of heliotrine, indicine$\mathrm{N}$-oxide, indicine, supinine, heleurine, lasiocarpine, rapanone and estradiol. ${ }^{4}$ Few aldehydes like phenylacetaldehyde (22.2\%), (E)-2-nonenal (8.3\%) and $(E$, $Z$ )-2-nonadienal (6.1\%), with a notable quantity of

Correspondence to: A.T.M. Zafrul Azam

Tel.+880-2-9661900/8190; Cell: +880-1710-880064;

Fax:+880-2-9667222; Email: zafrulazam@du.ac.bd

Dhaka Univ. J. Pharm. Sci. 15(1): 113-115, 2016 (June) hexahydrofarnesylacetone (8.4\%) and another pyrrolizidine alkaloid named as helindicine were identified with moderate antioxidant activity. ${ }^{5,6}$ Most of these alkaloids showed hepatotoxic activities and therefore, the internal use of this plant is not recommended. ${ }^{7}$ The aqueous extract of leaves of $H$. indicum was used in ulceration where dose dependent histo-gastroprotective effects were observed. ${ }^{8}$ As part of our ongoing investigations on medicinal plants of Bangladesh, ${ }^{9-11}$ the present work has been undertaken to isolate and identify biologically active secondary metabolites of the methanol extract of whole plant of $H$. indicum. We, herein, first report the isolation of 2,5-dihydroxy-3-heptadecyl-1,4-benzoquinone and the re-isolation of stigmasterol (2) from the extractive of $H$. indicum.

The ${ }^{1}$ HNMR spectra were recorded using a Bruker AMX400 (400 MHz) instrument and the spectra were referenced to the residual nondeuterated solvent signal. PTLC $(20 \times 20 \mathrm{~cm})$ and TLC $(20 \times 5$ $\mathrm{cm})$ were carried out using Merck Silica gel $60 \mathrm{PF}_{254}$ on glass plates at a thickness of $0.5 \mathrm{~mm}$. Spots on TLC and PTLC plates were visualized by spraying with vanillin-sulfuric acid followed by heating for 5 minutes at $110{ }^{\circ} \mathrm{C}$. All solvents used in this study were of reagent grade.

Aerial parts of the plant, $H$. indicum were collected from Comilla, Bangladesh in the month of June 2014. A voucher specimen (DACB-43063) for this collection has been deposited in Bangladesh 
National Herbarium, Mirpur, Dhaka for future reference.

The dried powdered aerial parts $(980 \mathrm{~g})$ of $H$. indicum was soaked in $2.5 \mathrm{~L}$ methanol for 10 days and filtered through a cotton plug followed by Whatman filter paper number 1 . The extract was then concentrated by using a Buchii Rotary Evaporator. A portion $(5.0 \mathrm{~g})$ of the concentrated methanol extract was fractionated by the modified Kupchan partitioning method ${ }^{12}$ into pet-ether (PF, $1.5 \mathrm{~g}$ ), dichloromethane (DCMF, $1.0 \mathrm{~g}$ ), chloroform (CF, 1.5 g) and aqueous soluble fractions (AF, $0.8 \mathrm{~g})$. The petroleum ether soluble partitionate was fractionated by column chromatography (CC) over silica gel (Kieselgel 60, mesh 100-200) using petroleum etherethyl acetate and ethyl acetate-methanol mixtures of increasing polarities to give 60 fractions (each 25 $\mathrm{ml}$ ). Preparative thin layer chromatography of fractions eluted with $25 \%$ ethyl acetate in petroleum ether afforded compound 1 namely 2,5-dihydroxy-3heptadecyl-1,4-benzoquinone. On the other hand, compound 2 namely stigmasterol was separated using $15 \%$ ethyl acetate in petroleum ether.
2,5-Dihydroxy-3-heptadecyl-1,4-benzoquinone (1). Colorless powder; ${ }^{1} \mathrm{H}$ NMR (500 $\left.\mathrm{MHz}, \mathrm{CDCl}_{3}\right)$ : $\delta 5.34(1 \mathrm{H}$, br. s, H-6), 2.34 (2H, t, J=7.5 Hz, H-1'), 2.00-1.25 (30H, m, H-2'-H-16'), 0.87 (3H, t, $J=6.5$ $\left.\mathrm{Hz}, \mathrm{H}-177^{\prime}\right)$.

The ${ }^{1} \mathrm{H}$ NMR spectrum (500 $\mathrm{MHz}, \mathrm{CDCl}_{3}$ ) of compound 1 showed a broad singlet $(J=10.0 \mathrm{~Hz}, 5.0$ $\mathrm{Hz})$ at $\delta 5.34$ which could be assigned for $\mathrm{H}-6$ of benzoquinone. The spectrum further showed a terminal methyl group (C-17') at $\delta 0.87(3 \mathrm{H}, \mathrm{t}, J=6.5$ $\mathrm{Hz})$. The methylene groups at $\delta 2.36(2 \mathrm{H}, \mathrm{m}, J=7.50$ $\mathrm{Hz}), \delta 2.00(2 \mathrm{H}, \mathrm{m}, J=6.5 \mathrm{~Hz})$ and $\delta 1.62(2 \mathrm{H}, \mathrm{m}$, $J=26 \mathrm{~Hz}$ ) could be assigned to $\mathrm{H}-\mathrm{1}^{\prime}$ to $\mathrm{H}-3^{\prime}$ of the heptadecyl chain. The methylene groups of C-4' to C16 were observed at $\delta 1.30$ that integrated for 26 protons. Although ${ }^{1} \mathrm{HNMR}$ data of this compound was not available for comparison but the ${ }^{1} \mathrm{H}$ NMR resonance was found to be in close agreement to those of embelin (2,5-dihydroxy-3-undecyl-1,4benzoquinone), rapanone (2,5-dihydroxy-3-tridecyl1,4-benzoquinone) and their alkyl derivatives. ${ }^{13-16}$

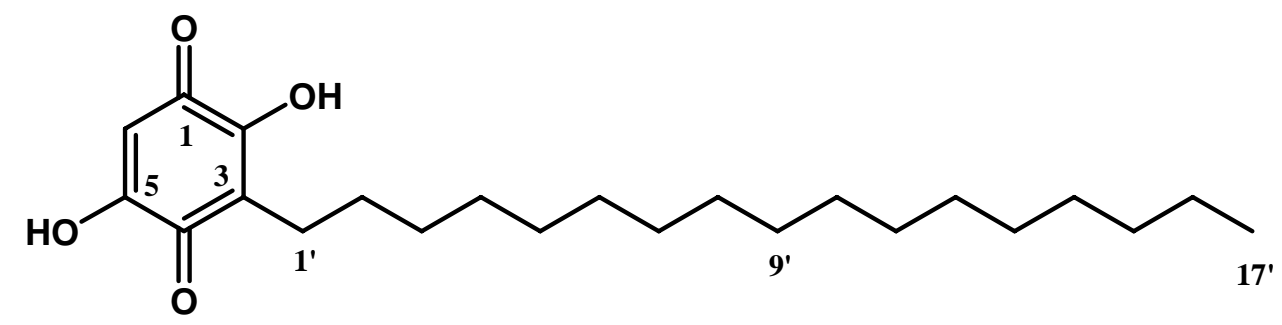

1<smiles>[17CH2]CCCCCCCCCCC1=C(O)C(=O)C=C(O)C1=O</smiles>

Embelin
Stigmasterol 2. ${ }^{1} \mathrm{H}$ NMR (500 $\left.\mathrm{MHz}, \mathrm{CDCl}_{3}\right)$ : Colorless gum; $\delta 5.2(1 \mathrm{H}$ br. s, $J=7 \mathrm{~Hz}, \mathrm{H}-6$ of a steroidal nucleus), 3.49 (m, H-3), multiplet signals at

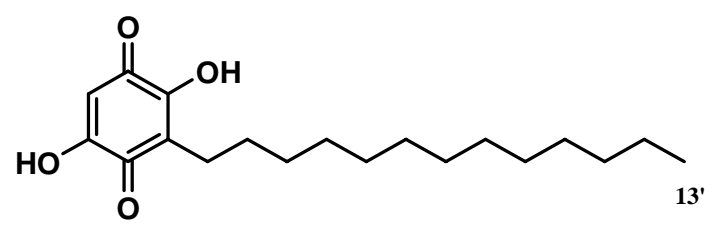

\section{Rapanone}

$\delta 1.14$ to $2.21\left(18 \mathrm{H}, 9 \times \mathrm{CH}_{2}\right.$ and $8 \mathrm{H}, \mathrm{CH}$ proton $)$ and $\delta$ 0.62 to 1.09 (multiplet, $18 \mathrm{H}, 6 \times \mathrm{CH}_{3}$ ). Based on the above data, the compound was confirmed as 
stigmasterol. ${ }^{17-19}$ The identity was further substantiated by co-TLC with authentic sample.

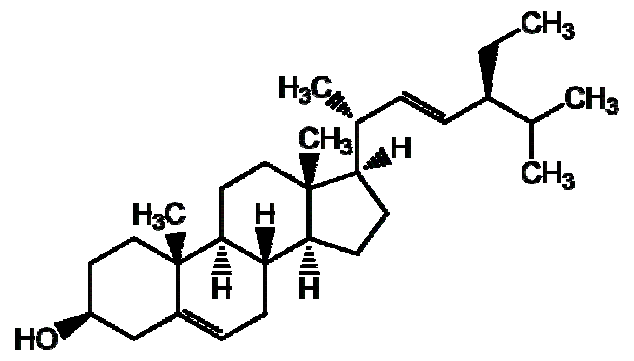

2

\section{REFERENCES}

1. Medicinal Plants Database of Bangladesh.

http://www.mpbd.info/plants/heliotropiumindicum.php.

2. Yusuf, M., Begum, J., Hoque, M. N. and Choudhury, J. U. 2009. Medicinal plants of Bangladesh-Revised and Enlarged. Bangladesh Coun. Sci. Ind. Res. Lab. Chittagong, Bangladesh.

3. Asolkar, L.V., Kakkar, K. K. and Chakre, O. J. 1992. Second Supplement to Glossary of Indian Medicinal Plants with Active Principles Part I (A-K). (1965-81). Publications and Information Directorate, Council of Scientific and Industrial Research (CSIR), New Delhi. India.

4. Protabase Record. 2012. Prota 11(1): Medicinal plants/ Plantesmédicinales 1. Record display. Consultado 23/01/2012. http://database.prota.org/PROTAhtmml/Plantago $\%$ 20lanceolata.

5. Ogunbinu, A.O., Flamini, G., Cioni, P.L., Adebayo, M.A. and Ogunwande, I.A. 2009. Constituents of Cajanus cajan (L.) Millsp., Moringa oleifera Lam., Heliotropium indicum L. and Bidenspilosa L. from Nigeria. Nat. Prod. Commun. 4, 573-578.

6. Souza, J.S.N., Machado, L.L., Pessoa, O.D.L., Braz-Filho, R., Overk, C.R., Yao, P., Cordell, G.A. and Lemos, T.L.G. 2005. Pyrrolizidine alkaloids from Heliotropium indicum. J. Braz. Chem. Soc. 16, 1410-1414.

7. Dash, G.K. and Abdullah, M.S. 2013. A review on Heliotropium indicum L (Boraginaceae). IJPSR. 4, 12531258.

8. Adelaja, A.A.,Ayoola, M.D., Otulana, J.O., Akinola, O.B., Olayiwola, A. and Ejiwunmi, A. B. 2008. Evaluation of the histo-gastroprotective and antimicrobial activities of Heliotropium indicum Linn (Boraginaceae). Malays. J. Med. Sci. 15, 22-30.
9. Sharmin, T., Islam, F., Kaisar, M.A., Uddin, M.G. and Rashid, M.A. 2012. Antioxidant, thrombolytic and cytotoxic activities of Picrasma javanica. Dhaka Univ. J. Pharm. Sci.11, 71-74.

10. Hossain, S.M., Islam, F., Sharmin, T., Sheikh, H., Hasan, A.M.R. and Rashid, M.A. 2012. In vitro antioxidant, membrane stabilizing and thrombolytic activities of Glycosmis arborea. Bangladesh Pharm. J. 15, 141-43.

11. Islam, F., Chowdhury, S.R., Sharmin, T., Uddin, M.G., Kaisar, M.A. and Rashid, M.A. 2013. In vitro membrane stabilizing and thrombolytic activities of Ophirrhiza mungos, Mussaendam acrophylla, Gmelina philippensis and Synedrella nodiflora growing in Bangladesh. J. Pharm. Nutr. Sci. 3, 71-75.

12. Van Wagenen, B.C., Larsen, R., Cardellina, J.H., Ran dazzo, D., Lidert, Z.C. and Swithenbank, C. 1993. Ulosantoin, a potent insecticide from the sponge Ulosa ruetzleri. J. Org. Chem. 58, 335-337.

13. Radhakrishnan, N., Gnanamani, A. andMandal, A.B. 2011. A potential antibacterial agent Embelin, a natural benzoquinone extracted from Embeliaribes. Bio. Med. 3, 1-7.

14. Manguro, L.O.A., Ugi, I. and Lemen, P. 2004.Further flavonol glycosides of Embelias chimperi leaves. Bull. Chem. Soc. Ethiop.18, 51-57.

15. Midiwo, J.O., Arot, L.O. and Odingo, J.O. 1990. Benzoqidnone pigments in kenyanmyrsinaceae: new 2, 5dlhydroxyalkyl derivatives from Maesalan ceolata. Bull. Chem. Soc. Ethiop. 4, 71-73.

16. Midiwo, J.O., Arot, L.M. and Mbakaya, C.L. 1988. Distribution of benzoquinone pigments in Kenyan Myrsinaceae. Bull. Chem. Soc. Ethiop. 2, 83-85.

17. Ahamed, B.K.M., Krishna, V., Gowdru, H.B., Rajanaika, H., Kumaraswamy, H.M., Rajshekarappa, S., Dandin, C.J. and Mahadevan, K.M. 2007. Isolation of bactericidal constituents from the stem bark extract of Grewiatilia efolia Vahl. Res. J. Med. Plants. 1, 72-82.

18. Jain, P.S. and Bari, S.B. 2010. Isolation of lupeol, stigmasterol and campesterol from petroleum ether extract of woody stem of Wrightia tinctoria. Asian J. Plant Sci. 9, 163167.

19. Kamboj, A. and Saluja, A.K. 2011. Isolation of stigmasterol and $\beta$-sitosterol from petroleum ether extract of aerial parts of Ageratum conyzoides (Asteraceae). Int. J. Pharm. Pharm. Sci. 3, 94-96. 